\title{
Adaptation of Globalization and Their Effect to the Tanzania Economic Growth
}

\author{
Japhet Jacksoni Katanga $^{1} \&$ Seleman Pharles ${ }^{2}$ \\ ${ }^{1}$ Zhejiang Normal University, China \\ ${ }^{2}$ University of Electronic Science and Technology of China, China \\ Correspondence: Japhet Jacksoni Katanga, Zhejiang Normal University, China. E-mail: \\ Katanga.japhet@yahoo.com
}

Received: May 15, 2018

doi:10.5539/ijbm.v13n8p217

\author{
Accepted: June 13, 2018 \\ Online Published: June 30, 2018 \\ URL: https://doi.org/10.5539/ijbm.v13n8p217
}

\begin{abstract}
Globalization can be defined as the process based on international cooperation strategies, the aims of globalization is to expand the operation of a certain business or service into a worldwide level, Globalization facilitates the modern advanced technology which helps community to undergo social, political and economic development. Globalization economic has reinforced the margination for African developing economies and made it to be dependent for the few primary commodities or service whereby the price and demand are extremely determined by outsiders. On this outcome it led some of the African countries being turned into poverty or economic inequality due letting their own resources being determined by developed countries. On this paper we analyze the effect of adaptation of globalization to Tanzania economic growth.
\end{abstract}

Keywords: adaption of globalization, effect of globalization, economic growth, International trade, Tanzania

\section{Introduction}

(Kuepper, June 19,2017) Globalization had impact on every aspect of modern human life and continues growing force in the certain global economy. While there were a few drawbacks to globalization, most economists agree that it's a force for both net beneficial and unstoppable to the world economy. Through the periods of protectionism and nationalism but globalization still continues to be the most widely acceptable solution to ensuring the consistent of economic growth in the world

(Kilic)Economic Globalization Index: The index includes two sub-indexes which were restrictions and actual flows. Actual flows are being calculated with GDP of trade percentages, foreign trade investments (FDI) and stocks, portfolio investments and income payment to foreign nationals. Come on restrictions are being calculated with hidden import barriers which mean tariff rate, current revenue percentages for taxes of international trade and capital account restrictions. Both restrictions and actual flows are immensity in economic globalization index is 50 percent.

$>$ Social Globalization Index: The index includes 3 sub-indexes which are cultural proximity personal contact and information flows. Personal contact was calculated with telephone traffic, international tourism, GDP percentages of transfers and the foreign population according to total amount of population and the international letters per capita.

$>$ Political Globalization Index: The index was calculated with 4 sub-indexes which are number of embassies in the country, membership of international organizations, participation in the (UN) United Nations Security Council and international treaties.

(Ibrahim, August 2013)Globalization refer as the process of intensification of political, economic, cultural and social relations across to international boundaries for the aimed of transcendental homogenization in socio-economic and political theory across the globe, the significant impacts on African countries through systematic restructuring of phases interactive among its nations, by breaking down barriers in the certain areas of commerce, culture, communication and several other fields. These processes have impelled series of cumulative international division of labor, economic distribution and political power; whereby African countries get pushed to qualifying in feature poverty, diseases, and unemployment. 


\subsection{Objective}

- To oversee whether the globalization is expanding financial integration

- How globalization affect the international trade

- How globalization is affecting the Foreign Direct Investment

- Whether the globalization is affecting the change standard of living

- How globalization is affecting the technical change

1.2 Risk growth for adaption of Globalization

(A shifting Global Economic Landscape, January 2017) The Risks which associate to the global growth outlook are the large emerging on market economies.

$\checkmark \quad$ High corporate debt

$\checkmark \quad$ Declining profitability

$\checkmark \quad$ Weak of the bank balance sheets

$\checkmark \quad$ Capital flows reversal and balance sheets implication of sharps depreciations.

$\checkmark \quad$ low commodity prices

(Kuepper, June 19,2017) His categories the global risk outcome due to appear of unequal distribution between developing and developed countries. The globalization risks include:

$>$ Interdependence. Globalization leads to the interdependence between the nations, which are able to cause the regional or global instabilities, if the local economic fluctuation end up impacting on large number of countries which rely on them (Pharles and Andre 2018)..

$>$ National Sovereignty. The rise of nation states, multinational, global firms or other international organizations could be as threat to sovereignty. On scenario could cause of some leaders to become nationalistic.

$>\quad$ Equity Distribution. The distribution of normal benefits of globalization is unfairly skewed towards the richest nation or individual, globalization creating a greater inequalities and it can lead to potential conflict both internationally and nationally as a result.

\section{Theoretical Literature Review}

(Pologeorgis, March 6,2017)Globalization compel businesses into adapted to different strategies concept based on the new ideological trend, which try to balance a right thing and interests for both individual and the whole community. On this change its able to push a competitive businesses to worldwide. (UNIVERSITY, May 2012) Impact of globalization has influenced massive change in our country, Tanzania had no health policy in the rural areas before 1990, but after the spread of the impact of globalization in Tanzania, health services were being introduced in (1990-2003) period. The main purpose of spreading health policies service in Tanzania was to improve the well-being of all Tanzania people and encouraged the health system to be more responsible to certain people

\subsection{Globalization and Tanzania Economy Policy}

(Nord) According to rapid growth of globalization and Millennium goals 2025, Tanzania has set up his goal/objective to make sure to reached the targets, these economic objective policy such as;

$>\quad$ Raise growth and Reduce Poverty (Mkukuta)

$>$ Maintaining macroeconomic stability

$>$ Durably strengthening public finances

$>$ Accelerating financial sector reform

$>$ Improving the business environment

\subsection{Globalization and Situation of Tanzania Economy}

(Africa Development Group, 2018)Economic growth has been slowed growth since 2016, following a real GDP economic growth of at least 7\% in (2013- 2016). On averaged of $6.8 \%$ has grown in the first and two quarter of 2017 and were estimated at $6.5 \%$ for the full year. Construction of infrastructure such as communication, mining sector and transportation were key factor of economic growth in 2017. Economic growth is a project which to remain robust at least $6.7 \%$ and $6.9 \%$ in 2018 and 2019 respectively, these represented one among of the best 
East Africa performances.

(Heritage Foundation, 2018) Tanzania's economic freedom score was 59.9, which making its economy to the 97th freest in 2018 Index. The overall score has increased by 1.3 points, with increased for judicial effective and its property rights outpacing at lower scores for the burden tax and indicators freedom for labor. Tanzania has ranked 10th position among of 47 countries in the Sub-Saharan Africa region, Trade its mostly important to Tanzania's economy, the combination values of the import and exports is equals to $37 \%$ of GDP. The government opened to foreign investment was below average. Also, small financial sector were involved. Credit was allocated largely at a certain market rates and a various commercial credit instruments were available to specific private sector. Below is a statistic graph which shows the different Tanzania economic grade into different years;

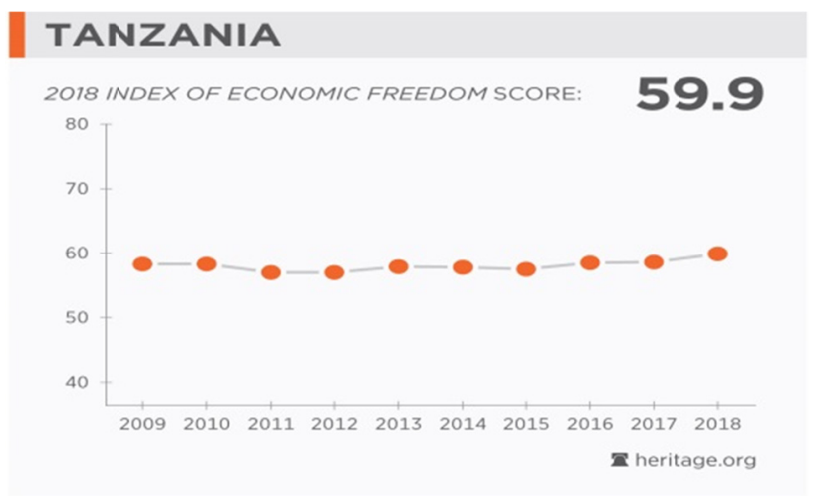

Source: (Heritage Foundation, 2018).

According to current economic situation 2018, the heritage foundation summarize the Regional ranking of economic changes, below its Table shown Regional ranking of economic.

Table 1. Regional ranking of economic

\begin{tabular}{llll}
\hline Rank & Countries & Raking Overall & Changes \\
\hline 1 & Mauritius & 75.1 & $0.4 \wedge$ \\
2 & Botswana & 69.9 & $-0.2 \vee$ \\
3 & Rwanda & 69.1 & $1.5 \wedge$ \\
4 & South Africa & 63 & $0.7 \wedge$ \\
5 & Uganda & 62 & $1.1 \wedge$ \\
6 & Cote d'lvoire & 62 & $-1.0 \vee$ \\
7 & Sychelles & 61.6 & $-0.2 \vee$ \\
8 & Bukina Faso & 60 & $0.4 \wedge$ \\
9 & Cabo Verde & 60 & $3.1 \wedge$ \\
10 & Tanzania & 59.9 & $1.3 \wedge$ \\
\hline
\end{tabular}

$\checkmark$ : Ranking Decreasing; $\wedge$ : Ranking increasing.

Source of information: (Heritage Foundation, 2018).

\subsection{Benefit of Adaptation Globalization to Economic Growth}

Globalization turned the world to become as a one community due to the faster technollogy growth and higher demand from individual or country. The world economists agreed for the rapid growth of globalization provides a positive benefit to the country or individual economies.

Foreign Direct Investment, Foreign Direct Investment tends to be increased at a maximum greater rate which indicate the economic growth in the world trade, foreign direct investment help a lot to boost technology transfer, industrial transfer to the country economic.

Efficient markets, more efficient markets consider on what economy strives for. A normal sign which shown a market is more efficient it's when there are equilibrium of buyer and seller to have a willing to pay or sell for the 
good or service at a certain market.

Technological Innovation. Globalization lead to increasing of the industry competition which stimulate to innovate the new technology development, increasing rate of Foreign direct investment automatically improved technology output of the country economy.

Economies of Scale. Large companies enable to realize the economies scale of the certain market that would help to reduce price and costs consumption, which can turns support into further to economic growth.

Increased competition, raising for more competitors who produce quality product and service to fight over a certain market located, each companies had to constantly looking the way of improved their service and goods to create customers loyalty.

Decreased Employment, The influence of foreign direct companies with new technology into developing like Tanzania, will help increases the rate of employment opportunity to many sectors, domestic companies worker were able to acquire some training skill to operate a modern machine technology on produce a quality product.

\section{Conceptual framework}

The independent variables of the project is rapid growth of globalization service which involved financial integration, International trade, Foreign Direct Investment (FDI), Technical change, change standard of living. The dependent variable in the study is Economic Growth

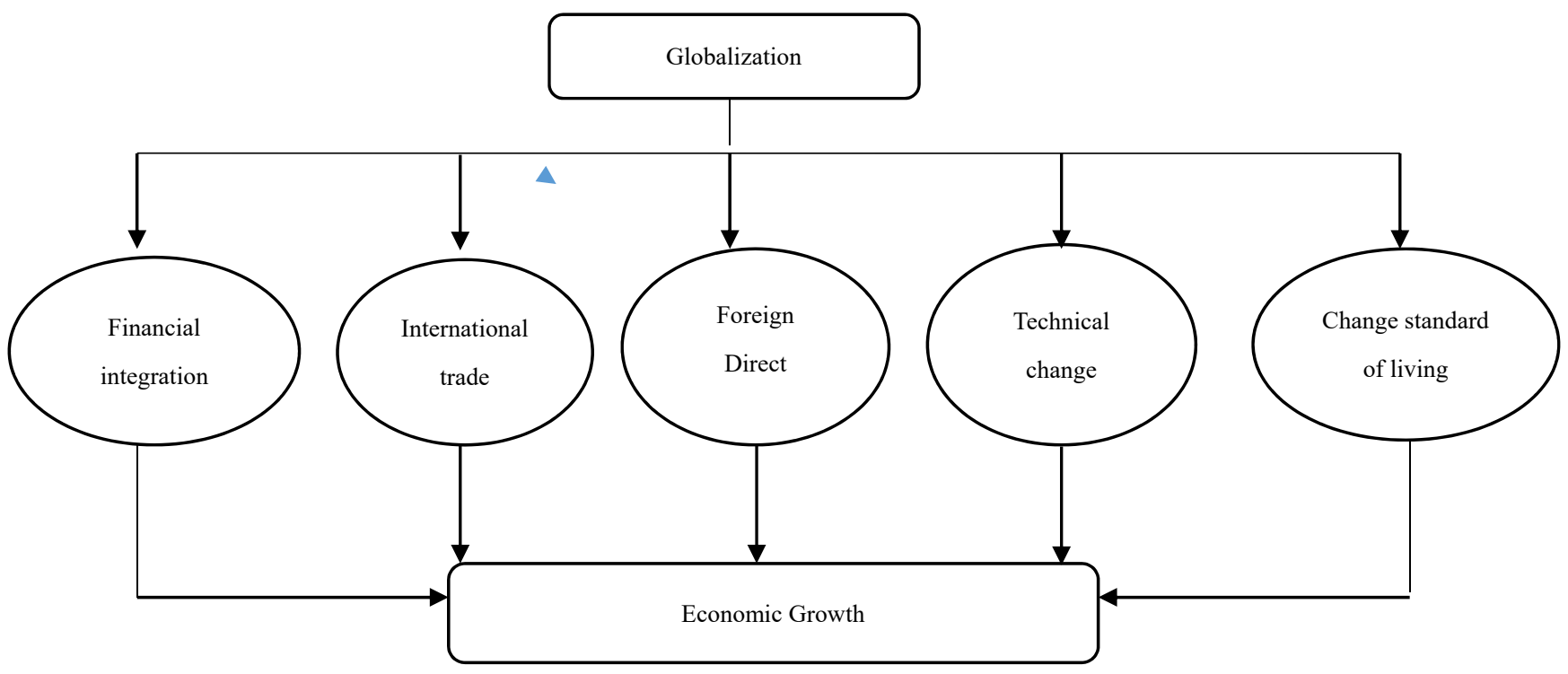

Sources: (Kilic).

From the above research conceptual model framework the following main hypothesis are developed.

H1-Financial integration is positively associated with Economic Growth

H2-International trade is positively associated with Economic Growth

H3-Foreign Direct Investment (FDI) is positively associated with Economic Growth

H4-Technical change is negative associated with Economic Growth

H5-Change standard of living is positively associated with Economic Growth

\section{Research Methodology}

Both primary and secondary data were collected to complete this research project, whereby the primary data were obtained in the field during the time study by the researchers and secondary data were obtained from different official documents. Researchers nominated 150 as a population sample and was achieved through random sampling methods. Researchers designed open and closed question through google doc form which allowed respondent to login direct and complete the specific questionnaire and resubmit online. The link was more convenient and send to all respondent through social media. Data were summarized through quantitative method and analyzed by using data processing software called SPSS. Researcher arranged the questionnaire according to rate scale which help respondent to fulfill the question as shown below: 
Table 2. Five point rate scale

\begin{tabular}{|c|c|c|c|c|c|}
\hline & Rating Scales & & & & \\
\hline \multirow{2}{*}{ Question } & 1 & 2 & 3 & 4 & 5 \\
\hline & High Dissatisfied & Dissatisfied & Partially Satisfied & Satisfied & High Satisfied \\
\hline
\end{tabular}

\section{Finding and Discussion}

\subsection{Validity and Reliability}

(Thanasegaran)The construction of validity and Reliability measures are directly concerned about the theoretical relationship of the variable. Its extent measure 'behaves' on the way that it construct purports of measure which should be behave with regard of established measures to other constructs.

Table 3. Reliability statistics

\begin{tabular}{lll}
\hline Cronbach's Alpha & Cronbach's Alpha Based on Standardized Items & N of Items \\
\hline .846 & .836 & 6 \\
\hline
\end{tabular}

According to the criteria of determine the best Cronbach's Alpha, the highest alpha should be 1.0 and should be greater than 0.5, 1.0<A>0.5. Cronbach's Alpha of our projects shown 0.846 which means of $80 \%$ of the combined 6 items variables, Cronbach's Alpha of our project indicate the true score internal consistence reliable variance.

Table 4. Correlations

\begin{tabular}{|c|c|c|c|c|c|c|c|}
\hline & & T.change & I.Trade & F.Integration & FDI & S.living & E.Growth \\
\hline \multirow{3}{*}{ T.change } & Pearson Correlation & 1 & -.056 & -.077 & -.061 & -.039 & -.116 \\
\hline & Sig. (2-tailed) & & .499 & .349 & .460 & .638 & .158 \\
\hline & $\mathrm{N}$ & 150 & 150 & 150 & 150 & 150 & 150 \\
\hline \multirow{3}{*}{ I.Trade } & Pearson Correlation & -.056 & 1 & $.859^{* *}$ & $.845^{* *}$ & $.826^{* *}$ & $.544^{* *}$ \\
\hline & Sig. (2-tailed) & .499 & & .000 & .000 & .000 & .000 \\
\hline & $\mathrm{N}$ & 150 & 150 & 150 & 150 & 150 & 150 \\
\hline \multirow{3}{*}{ F.Integration } & Pearson Correlation & -.077 & $.859^{* *}$ & 1 & $.842^{* *}$ & $.798^{* *}$ & $.516^{* *}$ \\
\hline & Sig. (2-tailed) & .349 & .000 & & .000 & .000 & .000 \\
\hline & $\mathrm{N}$ & 150 & 150 & 150 & 150 & 150 & 150 \\
\hline \multirow{3}{*}{ FDI } & Pearson Correlation & -.061 & $.845^{* *}$ & $.842^{* *}$ & 1 & $.885^{* *}$ & $.556^{* *}$ \\
\hline & Sig. (2-tailed) & .460 & .000 & .000 & & .000 & .000 \\
\hline & $\mathrm{N}$ & 150 & 150 & 150 & 150 & 150 & 150 \\
\hline \multirow{3}{*}{ S.living } & Pearson Correlation & -.039 & $.826^{* *}$ & $.798^{* *}$ & $.885^{* *}$ & 1 & $.564^{* *}$ \\
\hline & Sig. (2-tailed) & .638 & .000 & .000 & .000 & & .000 \\
\hline & $\mathrm{N}$ & 150 & 150 & 150 & 150 & 150 & 150 \\
\hline \multirow{3}{*}{ E.Growth } & Pearson Correlation & -.116 & $.544^{* *}$ & $.516^{* *}$ & $.556^{* *}$ & $.564^{* *}$ & 1 \\
\hline & Sig. (2-tailed) & .158 & .000 & .000 & .000 & .000 & \\
\hline & $\mathrm{N}$ & 150 & 150 & 150 & 150 & 150 & 150 \\
\hline
\end{tabular}

**. Correlation is significant at the 0.01 level (2-tailed)

Table shown a strong positive correlation between variable as increase or decrease of independent variable (I.Trade, F.Integration, FDI, and S.living) led to increase or decrease of Economic Growth while T.change variable which shown strong negative correlation with other variable and doesn't pass the T- test significant, according to T-test Sig. where $\mathrm{r}=.84, \mathrm{p}<0.01$, our table value other variable shown $\mathrm{p}$ value is equal to 0.000 , which means the actual capability of find this correlation is true of $\mathrm{p}<0.001$

\subsection{New factor Model}

Based on the correlation analysis result, Researchers found a new factor model which could help other 
researchers in future perspective projects, these new factor model involve four independent variables such as financial integration, International trade, Foreign Direct Investment (FDI) and change standard of living.

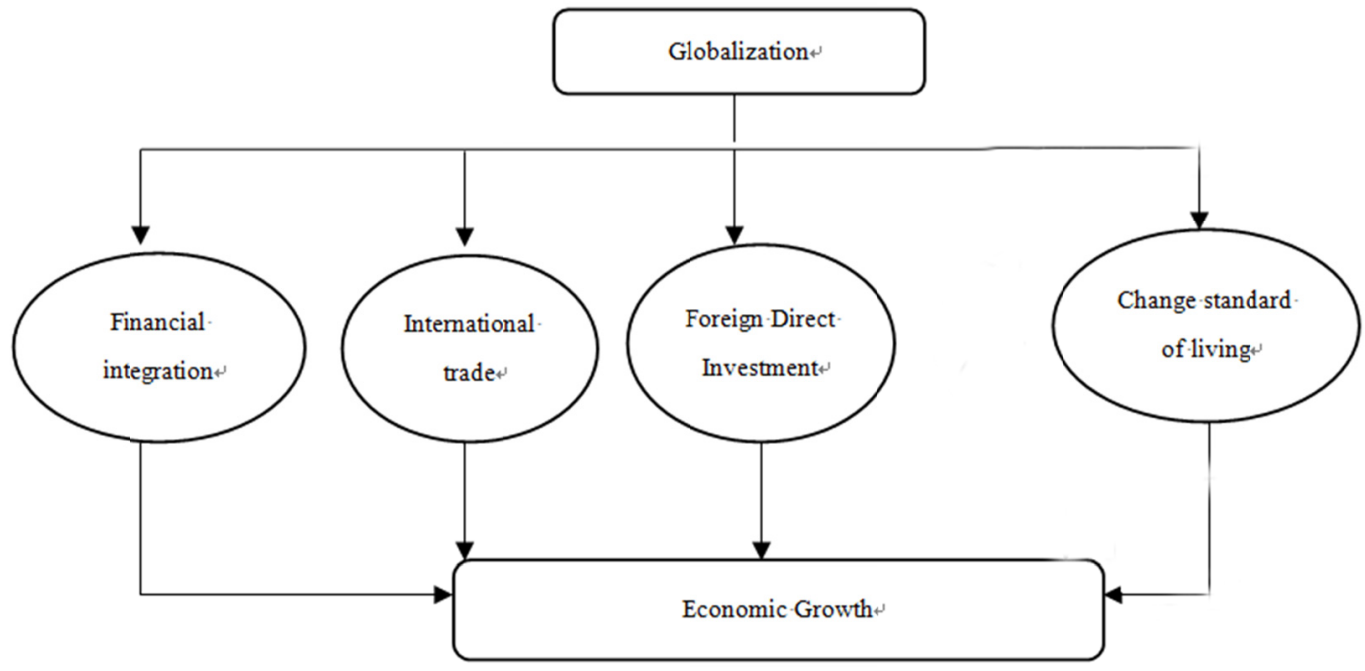

H1-Financial integration is positively associated with Economic Growth.

H2-International trade is positively associated with Economic Growth.

H3-Foreign Direct investment (FDI) is positively associated with Economic Growth.

H4-Change standard of living is positively associated with Economic Growth.

\section{Discussion and Conclusion}

According to the feedback which we got from the respondents, we observed their statistically significant correlation of Financial integration, International trade, Foreign Direct Investment (FDI), Change standard of living except technical change factor which shown a provision insignificant relationship to Economic Growth. So researcher ignore to mention technical change as a mainly factor for the economic growth. Researchers advise the government to pay more effort on International trade, Financial integration, Foreign Direct Investment (FDI) and change standard of living to Economic Growth. Also, researchers give big up to the Tanzania government for their effort of reconstructing infrastructure policies (mining, communication, transport) which was indicated as the most important key for raising economy in 2017. (UNIVERSITY, May 2012)Globalization creating employment. Through investment people got employments opportunities which help them to improve people's standard of living in the country. For example, foreign communication companies like Vodacom, Airtel, Zantel and Tigo have employed thousands of Tanzania's which help them to improve standard of living people in urban setting.

\section{References}

A shifting Global Economic Landscape. (January 2017). World Economic Landscape.

Africa Development Group. (2018). African Economic Outlook(AEO).

Heritage Foundation. (2018). 2018 index of Economic Freedom.

Ibrahim, A. A. (2013). The Impact of Globalization on Africa. International Journal of Humanities and Social Science, 3(15).

Kilic, C. (n.d.). Effects of Globalization on Economic Growth: Panel Data Analysis for Developing Countries. Economic Insights - Trends and Challenges, 1-11.

Kuepper, J. (2017). Globalization and its impacts on Economic Growth.

Nord, R. (n.d.). Economic Policy Objectives and Challenges in Tanzania.

Pologeorgis, N. (2017). How Globalization Affects Developed countries.

Pharles, S and Andre, C. (2018). Environmental impacts of globalization in Tanzania:

Assessing its effects and measures taken by the Government of Tanzania. Int. J. Polit. Sci. Develop. 6(1) 1-15 
Thanasegaran, G. (n.d.). Reliability and Validity issues in Research.

University, C. A. (2012). What are the impact of globalization in Tanzania rural and urban setting?

\section{Copyrights}

Copyright for this article is retained by the author(s), with first publication rights granted to the journal.

This is an open-access article distributed under the terms and conditions of the Creative Commons Attribution license (http://creativecommons.org/licenses/by/4.0/). 